\title{
The Conduct of Operations: Glubb Pasha, the Arab Legion, and the First Arab-Israeli War, 1948-49
}

War in History 2019, Vol. 26(4) 539-562 (C) The Author(s) 2018 (c) (1) (8)

Article reuse guidelines: sagepub.com/journals-permissions DOI: I0.1 I77/09683445 I772554 I journals.sagepub.com/home/wih

\section{Matthew Hughes}

Brunel University, UK

\begin{abstract}
The recent accession by St Antony's College Oxford of papers from British army officer John Bagot Glubb, commander of Transjordan's Arab Legion, affords a remarkable opportunity to test and reimagine significant debates surrounding the first Arab-Israeli war. Glubb's papers establish two points. First, that military operational necessity best explains the actions of the Arab Legion in 1948 and that this was more important than the political objective by Transjordan and Israel to collude to divide Palestine. Second, the papers offer a new, augmented military history of the war taking into account daunting command and logistical challenges faced by the Legion.
\end{abstract}

\section{Keywords}

Arab Legion, King Abdullah, Glubb Pasha, Avi Shlaim, logistics

This article is a revised military history of Transjordan's British-led 'Arab Legion' army in the 1948-49 Arab-Israeli war, connecting military imperatives - the conduct of operations - to the politics of the war. Such a history reimagines significant debates on the Legion's military effectiveness, the role of its British commander General Sir John Bagot Glubb 'Pasha', and on the relationship of policy to military operations, notably Avi Shlaim's argument that Transjordan and Israel colluded politically to divide Palestine and that military operations followed this policy objective, a perspective recently updated by Graham Jevon. ${ }^{1}$ The history here substantially augments and

1 Avi Shlaim, Collusion: King Abdullah, the Zionist Movement, and the Partition of Palestine (Oxford, 1988); Graham Jevon, 'The Arab Legion and the 1948 War: The Conduct of “Collusion”?', English Historical Review 130/545 (2015), pp. 907-33.

\section{Corresponding author:}

Matthew Hughes, Department of Politics and History, Brunel University, Kingston Lane, Uxbridge UB8 3PH, UK. Email: matthew.hughes@brunel.ac.uk 
at times challenges the corpus on the politics of the 1948 war, including the work of Shlaim and Jevon, and supplements broader military histories examining the link between operations, strategy, and policy. This study starts by briefly detailing the Legion's force and command structure, as an understanding of its military hierarchy makes possible the substantive argument of the main body of this article on the Legion's military-political part in the 1948 war, one that draws on new evidence from Glubb's recently released private papers.

\section{The Arab Legion}

The army of King Abdullah's Transjordan that went to war with Israel in the ArabIsraeli conflict of 1948-49 - the Arab Legion, later the Jordanian army - was a remarkable military unit. First, some 37 British officers and 25 British non-commissioned officers (NCOs) led the army; second, the Legion was the most effective Arab army in 1948, in large measure because Britain as Abdullah's ally led, funded, trained, and equipped it. ${ }^{2}$ It was the only Arab army in 1948 that covered itself in glory, defeating Israel in two sets of battles in and around Jerusalem's old city and at Latrun (15 May-18 July), interrupted by a ceasefire (11 June-8 July). Most British Servicemen in the Legion were seconded from the British army, some had private contracts with Abdullah, and three were detached from the colonial service, including the Arabic-speaking supreme commander of the Legion, former army officer John Bagot Glubb. Glubb's deputy was Jordanian Major-General Abd al-Qadir al-Jundi. Israel inflated the British personnel numbers to 350, to include British soldiers with Arab irregular units and in supernumerary capacities with the Legion, some having deserted British forces as they withdrew from Palestine in 1948. ${ }^{3}$ Israel saw the hand of mercenary former Nazi soldiers and Arabic-speaking Englishmen 'behind the disorderly, primitive Arab bands', a reference to the irregular Arab troops that served alongside the Legion, and Jerusalem's Anglican Bishop came upon British casualties in the city's Austrian hospice, 'personnel who absconded from the Palestine Police, I presume, and joined Arab forces'. ${ }^{4}$ British personnel numbers with the Legion fluctuated, London nominally withdrawing those officially contracted on 30 May 1948, but British soldiers commanded throughout the war at divisional, brigade, and regimental/battalion level, and they led three of the four

2 FO to UK Delegation (UN), 28 May, 1948, FO371/68829, T[he] N[ational] A[rchives]; Telegram, Amman to FO, 28 May 1948, FO371/68829, TNA; Benny Morris, The Road to Jerusalem: Glubb Pasha, Palestine and the Jews (London, 2002), p. 122.

3 FO to UK Delegation (UN), 28 May, 1948, FO371/68829, TNA; Amman to FO, 28 May 1948, FO371/68829, TNA; Draft paper, Disbandment, 2009-08-51-32 Lunt Papers, N[ational] A[rmy] M[useum]; Harry Levin, Jerusalem Embattled: A Diary of the City Under Siege [1950] (London, 1997), p. 205.

4 Levin, Jerusalem Embattled, pp. 94-5; Letter [from Hugh Jones?], Christchurch Jerusalem, 29 May 1948, 2006 Accession, Box 83, File November 1948, GB165-0118 Glubb Papers, M[iddle] E[ast] C[entre] St Antony's College Oxford; Diary of Events, Christchurch Jerusalem, 15 May 1948, 2006 Accession, Box 83, File November 1948, GB165-0118 Glubb Papers, MEC. See also Jerusalem to Foreign Office, 19 May 1948, FO371/68853, TNA. 
mechanized infantry regiments $\left(1^{\text {st }}, 2^{\text {nd }}, 3^{\text {rd }}\right.$, and $\left.4^{\text {th }}\right)$ ready on 15 May 1948 . These regiments were actually lorry-borne 800 -strong infantry battalions, a point to bear in mind in this study.

Manoeuvre war against Israel depended on the Legion's mechanized regiments that Glubb expanded over the course of the war. British officers occupied second-in-command and staff roles in these regiments, replacing wounded British regimental commanders. British soldiers commanded at the highest levels, conducted the vital staff work, and fought at the front against the Israelis, including Glubb who when visiting forward units talked to his officers in the open as shells exploded near them. Jordanians filled some command roles. Colonel Habis al-Majali led one of the mechanized regiments (the $4^{\text {th }}$ ) and Jordanians held second-in-command regimental roles; Jordanians filled company commander posts within mechanized regiments. There were also at least four Jordanian-led separate independent 100 -strong garrison companies $\left(1^{\text {st }}, 5^{\text {th }}, 8^{\text {th }}\right.$ and $\left.12^{\text {th }}\right)$, two of which ( $1^{\text {st }}$ and $8^{\text {th }}$ ) were the first to go into action in Jerusalem's old city on 18 May 1948. ${ }^{5}$ The garrison companies fulfilled static defence roles. In May 1948, the four mechanized regiments were formed into two brigades $\left(1^{\text {st }}\right.$ and the $\left.3^{\text {rd }}\right)$ commanded respectively by British colonels Desmond Goldie and 'Teal' Ashton in the $1^{\text {st }}$ Division. British Brigadier Norman Lash led this division, to which was also attached a fourcompany strong dummy $4^{\text {th }}$ Brigade based nominally in Ramallah, there to deceive the Israelis, and commanded by Jordanian Colonel Ahmad Sidqi al-Jundi. Similarly, the blank space for the $2^{\text {nd }}$ Brigade was to trick the Israelis into thinking that the Legion was a larger force, with four and not two brigades. The $2^{\text {nd }}$ Brigade later became operational; the $4^{\text {th }}$ Brigade eventually became fully operational, too. The $5^{\text {th }}$ and $6^{\text {th }}$ mechanized regiments - commanded by British officers Sam Sidney and Arthur Cooke, the latter later replacing Lash - were raised in June 1948 by amalgamating independent garrison companies with new recruits and they eventually went into the (British-led) $2^{\text {nd }}$ Brigade. These two regiments were initially attached to the $4^{\text {th }}$ Brigade as it became operational and were in independent action already by 19 May 1948 in Jerusalem, according to Legion war diaries, as the $5^{\text {th }}$ and $6^{\text {th }}$ 'MR'. ${ }^{6}$ There was a $7^{\text {th }}$ Mechanized Regiment by November 1948; more followed. British influence extended to the specialist support corps that made a modern army function: signals, supply, engineers, and artillery. Put simply, British officers filled supreme and field command posts, and the staff officer positions, and they led the specialist support arms. ${ }^{7}$ The quality of officers was generally good. One 'used to drink a lot', questions on the 'standard of leadership' were raised about another, while some came from the Palestine police with no military training, but

5 Syed Ali El-Edroos, The Hashemite Arab Army, 1908-1975: An Appreciation and Analysis of Military Operations (Amman, 1980), pp. 249-51.

6 James Lunt, The Arab Legion (London, 1999), pp. 114-17; Arab Legion War Diary, May 1948, 2006 Accession, Box 31, GB165-0118 Glubb Papers, MEC; Arab Legion, Operational Log/War Diary, May 1948, 2006 Accession, Box 90, Bundle Misc Dates, Part 3 of 3, GB165-0118 Glubb Papers, MEC.

7 El-Edroos, Hashemite Arab Army, p. 749; Arab Legion, War Diary, 1948, 2006 Accession, Box 31, GB165-0118 Glubb Papers, MEC. 
most came from regular British units and had fought in the Second World War. ${ }^{8}$ There were at least four British officers per battalion. ${ }^{9}$ There was no racial bar to Jordanians holding senior command but they filled just seven of 44 officer posts at the rank of major and above in May 1948. ${ }^{10}$ In September 1949, British official rolls record 46 of their army officers with the Legion. ${ }^{11}$ Through these command posts, Glubb and the British controlled the Legion as an operational divisional formation, even if it was Abdullah's army. An Israeli officer who had served in the British army observed that the Legion 'followed the British manual of operations to the last detail' ${ }^{12}$

In May 1948, the force numbered 6,000 soldiers, of which 4,500 were ready for frontline battle, paid and equipped by the British; by the war's end in March 1949, the Legion had boosted its numbers to $14,700 .^{13}$ There was no air force, although the British discussed forming one and personnel files from 1949 list British 'air force' officers with the Legion. ${ }^{14}$ The force had in May 1948 two powerful 25-pounder batteries each of four guns, one to each brigade - commanded by British officers with British NCO instructors - alongside larger numbers of smaller guns and mortars. ${ }^{15}$ The British had designed the Legion to fight alongside the British army, a point to bear in mind as all equipment resupply relied on Britain, by way of British Middle East Land Forces (MELF) depots in Egypt and RAF bases in Transjordan. ${ }^{16}$ Legionnaires served three-year enlistments with an option to re-enlist, but there was no reserve force ready in May 1948, although Amman had introduced a new reserve recruit law in December 1947. ${ }^{17}$ Britain funded the Legion to the sum of $£ 2.5$ million per annum by May $1948 .{ }^{18}$ Through its supply of leadership, money, and equipment, Britain could manipulate Abdullah and the Legion, as Glubb knew: 'It had been the British Foreign Office policy to keep Abdullah short of

8 Glubb to Lunt, 24 August 1980, 2009-08-51-89 Lunt Papers, NAM; interview, Nigel Bromage, 9 December 1980, 2009-08-51-90 Lunt Papers, NAM; AG to VCIGS, 23 November 1950, WO216/719, TNA.

9 Glubb to Kirkbride, 27 May 1950, FO816/165, TNA.

10 Ronen Yitzhak, Abdullah al-Tall: Arab Legion Officer (Brighton, 2012), p. 25.

11 Arab Legion British Personnel, FO816/152, TNA.

12 Levin, Jerusalem Embattled, p. 184.

13 El-Edroos, Hashemite Arab Army, pp. 249-51; Note, Arab Legion Strength, Strength on 31/3/49, 2006 Accession, Box 3, No. 5, File Two, GB165-0118 Glubb Papers, MEC.

14 Arab Legion Air Force 1946-8, FO816/94, TNA; Treasury Arab Legion, T220/126, TNA; Arab Legion British Personnel, FO816/152, TNA.

15 Chapter 6, Draft, Opposing Forces of Arab Legion, p. 18, 2006 Accession, Box 84, Bundle November 1948 Finished with 10/10/56, GB165-0118 Glubb Papers, MEC; James Lunt, Glubb Pasha: A Biography (London, 1984), p. 140.

16 Note, Reorganization of Arab Legion, May 1947, p. 6, 1986 accession, Box 14, GB1650118 Glubb papers, MEC.

17 Note, Reorganization of Arab Legion, May 1947, p. 6, 1986 accession, Box 14, GB1650118 Glubb papers, MEC, p. 8; El-Edroos, Hashemite Arab Army, p. 250; Reserves Scheme, p. 1, Box 1, File 10, Melville papers GB 165-0577, MEC.

18 Chapter 6, Draft, Opposing Forces of Arab Legion, p. 19, 2006 Accession, Box 84, Bundle November 1948 Finished with 10/10/56, GB165-0118 Glubb Papers, MEC. 
ammunition, a policy designed to act as a curb to any possible ambitions that he might have, and also to prevent his suddenly attacking one of his rivals.' 19

\section{The politics of war}

Abdullah's expansionist 'ambitions' intrigued scholars interested in the politics surrounding the 1948 war - a hugely significant conflict resulting in Israel's formation and the Palestinian refugee crisis - and in the 1980s Uri Bar-Joseph, Ilan Pappé, and Avi Shlaim broke new ground with studies of collusion between Abdullah and the Zionists to divide Palestine, and of Britain's complicity in this arrangement. ${ }^{20}$ As Shlaim wrote, there had 'been countless studies of the military operations of the 1948 Arab-Israeli war but very few writers have studied seriously the politics of that war'. ${ }^{21}$ What Shlaim meant by 'collusion' provoked heated debate and criticism of Shlaim's use of this term - and so a revised, toned down title of 'the politics of partition' for the paperback edition of his book - but these revisionist historians saw a political understanding or tacit agreement between Abdullah and the Zionists over Palestine that allowed both sides to avoid war to mutual territorial advantage. ${ }^{22}$ Shlaim regretted the change of title for the paperback edition and later wrote of a 'conspiracy'. ${ }^{23}$ Thus, narrow military operations followed with Clausewitzian logic to broader policy objectives jointly to occupy Palestine and avoid a clash of arms. Localized, exceptional friction points meant fighting at Jerusalem and Latrun, but the two parties were still the 'best of enemies', to borrow Bar-Joseph's book title. Tancred Bradshaw, Efraim Karsh, Benny Morris, and Avraham Sela later developed and reviewed the idea of an understanding between Transjordan and Israel, Karsh arguing that there never was any agreement, Sela talking of a 'collusion myth'. ${ }^{24}$ Two academic camps had emerged: on the one side, a secret political deal between Britain, the Jews, and Abdullah to divide Palestine; on the other, the idea that political enmity and military opportunism characterized the actions of the key players in 1948.

Then in 2006 St Antony's College Oxford acquired an immense tranche of Glubb's papers, offering a unique insight - a neo-revisionist view - into the Arab side of the Arab - Israeli conflict from the viewpoint of a senior British officer commanding Arab troops;

19 Chapter 6, Draft, Opposing Forces of Arab Legion, p. 19, 2006 Accession, Box 84, Bundle November 1948 Finished with 10/10/56, GB165-0118 Glubb Papers, MEC.

20 Uri Bar-Joseph, Best of Enemies: Israel and Transjordan in the War of 1948 (London, 1987); Shlaim, Collusion across the Jordan; Ilan Pappé, Britain and the Arab-Israeli Conflict, 1948-51 (Houndmills, 1988).

21 Shlaim, Collusion, p. 231.

22 Avi Shlaim, 'The Debate about 1948', International Journal of Middle East Studies 27/3 (1995), pp. 287-304.

23 Shlaim, 'Debate about 1948', p. 298; Avi Shlaim, Lion of Jordan: The Life of King Hussein in War and Peace (New York, 2007), p. 33.

24 Morris, Road to Jerusalem; Tancred Bradshaw, 'History Invented: The BritishTransjordanian Collusion Revisited', Middle Eastern Studies 43/1 (2007), pp. 21-43; Efraim Karsh, Fabricating Israeli History: The 'New Historians' (London, 1997); Avraham Sela, 'Transjordan, Israel and the 1948 War: Myth, Historiography and Reality', Middle Eastern Studies 28/4 (1992), pp. 623-88, 680. 
this offers a remarkable window on events as primary Arab material on the war is rare. The archive has still not fully catalogued the papers. Jevon used this material for his recent studies of the war, supporting Shlaim's thesis and, arguing that the 'conduct of collusion' - 'a work in progress' - meant a limited military campaign, and that any battles did not disprove the thesis that the two sides had an agreement; indeed, the fighting in Jerusalem provided an alibi for the partition elsewhere. ${ }^{25}$ As Jevon puts it, Glubb restrained the Legion and 'planned military offensives in terms of political outcomes' ${ }^{26}$ Shlaim and Jevon are sensitive to the issue that military action had a logic of its own and that subordinate commanders acted independently to charged events on the ground - 'plain military realities, without resorting to elaborate conspiracy theories', as Shlaim describes it - but their emphasis is on the politics of war and how military operations followed political imperatives. ${ }^{27}$

This article does not debunk the collusion thesis that political demands underpinned military operations; rather, it rebalances and augments the corpus on the 1948 war by using Glubb's papers to put war back into politics and argue that operational military contingencies as Glubb saw them offer an alternate explanation for the motives of the Legion. Moreover, Glubb's papers set alongside other British files create an improved military history of the Legion. While such a history developed from British officers such as Glubb is partial, it opens up new areas of debate on how the British viewed and influenced the Legion through their control of the force's officers, funding, and military supplies. This study places the war centre stage and argues that military needs - as articulated by Glubb the local commander - drove forward the deployment and actions of the Legion, and that we should balance operational necessity against policy objectives in our understanding of the Legion.

\section{Glubb's operational thinking}

When asked in 1978 on BBC Radio's Desert Island Disc programme what he would be happiest to escape on his desert island, Glubb retorted, 'politicians, all the time'. ${ }^{28}$ Glubb may have had 'a soldier's aversion to politics - and to politicians' but he was party to political discussions on the treaty status of Transjordan with the UK and on the future of Palestine prior to war in May 1948, most recently in February 1948 when he accompanied a Transjordanian delegation visiting London. ${ }^{29} \mathrm{He}$ was a central figure in talks between London and Amman and in discussions with the Jews and with Abdullah, and he knew that political imperatives would complicate the Legion's deployment, commenting later that the fighting in 1948 'was a curious imitation of a war, artificially limited by political considerations' ${ }^{30}$ Britain hoped to restrict Legion operations in any war with Israel to the

25 Graham Jevon, 'Jordan, Palestine and the British World System, 1945-57: Glubb Pasha and the Arab Legion' (Oxford: Doctoral Thesis, 2014); Jevon, 'Arab Legion'.

26 Jevon, 'Arab Legion', p. 930.

27 Shlaim, Collusion, p. 235.

28 Glubb, Desert Island Discs, BBC Radio 4, 18 April 1978.

29 Glubb, Revised Dictionary of National Biography.

30 Chapter, Draft, by Glubb, p. 1, 2006 Accession, Box 84, Bundle November 1948 Finished with 10/10/56, GB165-0118 Glubb Papers, MEC; J. B. Glubb, A Soldier with the Arabs (London, 1957), p. 89. 
Arab areas allotted by the November 1947 United Nations' Palestine partition plan, and Glubb - while Abdullah's 'great friend' and 'very fond' of the Arabs, recalled Goldie, whom Glubb sent to negotiate secretly with the Zionists before the war - had his part in this plan. ${ }^{31}$ As Glubb wrote to Lash on 9 July 1948, 'All of this is really going back to the original scheme before May $15^{\text {th }}$ of holding the Arab areas and doing nothing. ${ }^{32}$ Glubb balanced competing political demands from Abdullah and Jordanian Legion officers with those emanating from London and passed by way of Sir Alec Kirkbride, the British Legation Minister in Amman, MELF commander General Sir John Crocker, and the War Office in London. Thus, on 19 May 1948, as the Legion rolled into Jerusalem, the Foreign Office told Kirkbride, 'You should at the same time take the opportunity of rubbing in the point about Jerusalem... A full-scale Arab Legion attack on Jerusalem is exactly the kind of situation which would produce the greatest possible difficulty for us in our relations with Transjordan. ${ }^{33}$ Glubb's papers express these political pressures. The issue is the degree to which political considerations influenced Glubb's handling of the Legion. Was Glubb a political general, or rather a commander burdened by politics?

Had the Israelis been less aggressive in Jerusalem in their Kilshon (Pitchfork) operation from 13 May, Glubb could have had his phoney war and implemented the pre-existing arrangement peacefully to divide Palestine, and so avoid Israeli forces mauling his inchoate Legion. The Jewish push into Jerusalem's old city and eastern Arab areas of the city as the last British forces withdrew on 13-14 May so alarmed Abdullah that he pressured Glubb to save what remained of the Palestinian parts of the city and its holy sites. Glubb hesitated for several days in the hope that he could avoid war, fearful that street fighting would chew up his legionnaires and ruin his precious corps d'elite. This is well known. Israeli advances forced Legion garrison-company troops into Jerusalem's old city from the Mount of Olives on 18 May before Legion mechanized forces arrived from the north on the 19th through Sheikh Jarrah to the Damascus Gate where they fanned out and fought for two weeks in the old city and its environs. This included the seesaw fight for the immense Nôtre Dame building opposite the old city's New Gate, near to which Israeli mortar fire seriously wounded Major Bob Slade in charge of the $2^{\text {nd }}$ Mechanized Regiment, Major Geoffrey Lockett replacing him. ${ }^{34}$ A mortar round also wounded the second-incommand of the $2^{\text {nd }}$ Mechanized Regiment, Major Buchanan, in the same action; similarly, Israeli fire wounded the Australian officer Bill Newman, another regimental commander. ${ }^{35}$ Nôtre Dame overlooked the Legion's line of advance and its positions by the Damascus Gate and the force needed to take it. The Legion called off the battle for Nôtre Dame on 24 May, as it had no reserves to replace its shattered front-line troops, and just a fortnight's ammunition in stocks. ${ }^{36}$ The unfolding action around the old city

31 Avi Shlaim, interview with Colonel Desmond Goldie, 15 September 1985 (transcript from Shlaim via Jevon).

32 Glubb to Lash, 9 July 1948, 2006 Accession, Box 83, File November 1948, GB165-0118 Glubb Papers, MEC.

33 Foreign Office to Kirkbride, 19 May 1948, FO371/68853, TNA.

34 Maan Abu Nowar, The Jordanian-Israeli War, 1948-51 (Reading, 2002), p. 137.

35 Abu Nowar, The Jordanian-Israeli War, p. 116.

36 El-Edroos, Hashemite Arab Army, p. 255. 
prompted a linked battle 25 kilometres to the west for the hilltop police fort at Latrun that extended to July 1948. There was an earlier Legion attack on the Gush Etzion Jewish settlements south of Jerusalem on 12 May that captured the place, led by local Jordanian commanders, that Glubb agreed to for logistical reasons to keep open the HebronJerusalem road as Legion supplies from British depots in Egypt in the early stages of the war came overland via this route and Gush Etzion interdicted the road. ${ }^{37}$

Once Israeli military advances and Abdullah's fears had forced Glubb's hand and he intervened, Glubb's reading of history, his feel for topography, and his reaction to operational requirements determined his conduct of the Legion. Glubb as a soldier segued from politics to war. Glubb was reluctant to start the fight with Israel for political as well as military reasons but once Israeli advances forced him into war, he was not reluctant to fight, and operational restrictions and not politics informed his conduct of operations. This argument requires a reading of Glubb's papers as a record of army operations rather than (or as well as) political manoeuvrings, from a military rather than diplomatic perspective, and one that presents Glubb foremost as a soldier. Politics forced Glubb's troops into war but it provides a partial explanation for their actions thereafter. This requires readers to accept two propositions. First, that Glubb was fully in command of the Legion through his control of British officers, as detailed above. Second, that once battle commenced, and with soldiers on the ground now in the ascendant, the Legion necessarily followed military and not political logic. BarJoseph and Morris suggest that Abdullah used Jordanian officers such as Major Abdullah al-Tall (or al-Tel) to circumvent Glubb. ${ }^{38}$ There was unit autonomy at company level where Jordanians held field command, but in 1948 only al-Tall and captains Ali al-Hiyari, Ya'qub al-Salti, and Sadiq al-Shar'a had attended a junior British staff college. ${ }^{39}$ Jordanian officers lacked the training to handle the Legion as a complete force and Glubb's papers give no sense that he felt undercut in the field by secret Jordanian military manoeuvres. Command of battalions, brigades, and the Legion as a full division demanded senior-level staff work, and British logistical backup. The Legion could not function as a unit without the trained British officers who had spent years forming the force. When Legion soldiers stole carpets from a church in Jerusalem, Anglican church staff overheard al-Tall saying that any man caught looting would be arrested, before British Major James Hankin Turvin arrived 'to apologise' as he was in charge overall. ${ }^{40}$ British command structures made the force so effective against Israel; this led to an influx rather than a reduction of British officers. For instance, a British 'sapper major' formed the first field engineer unit when he 'borrowed a subaltern from the departing British forces in Palestine, and gathered thirty to forty men from various Legion units' and 'the First Field Unit began with two British sapper officers and, it seems, an Irish sapper NCO who had deserted the

37 Ronen Yitzhak, 'Transjordan's Attack on the Etzion Bloc during the 1948 War', Israel Affairs 17/2 (2011), pp. 194-207.

38 Bar-Joseph, Best of Enemies, pp. 62, 70-3; Morris, Road to Jerusalem, p. 161.

39 Abu Nowar, Jordanian-Israeli War, p. 71.

40 General Report 27, ACMI (Jerusalem, St George's) to Bishop, 24 July 1948, 2006 Accession, Box 83, File November 1948, GB165-0118 Glubb Papers, MEC. 
British forces in Palestine'. ${ }^{41}$ Dozens of ex-British officers and NCOs joined up as war began according to another source. ${ }^{42}$

\section{Glubb and history}

Seeing Glubb as a historian gives fresh insight on to how he perceived the operational issues surrounding the battle for Palestine. By the end of his life in 1986, Glubb had written some twenty-two books, the first published in 1943 on the Yezidis, mostly on the Arabs, Islam, and the Middle East, alongside several autobiographical accounts of his military experiences, and a history of the Legion published in 1948. His private papers are full of draft chapters from different volumes. Glubb was also a 'devout Christian' with an intimate passion for and knowledge of the Holy Land, and on the birth of his son in 1939 named him Godfrey after the Crusader king. ${ }^{43}$ As a Royal Engineer, Glubb had gone through the military academy at Woolwich in 1914, but he never passed staff college, instead spending the years after 1920 in Iraq and Transjordan on small-unit patrols. The Crusaders, history over the longue durée, religion, religious wars, Islam, the Arabs, and the Bible filled Glubb's histories and informed his operational understanding of the unfolding war in Palestine. Glubb connected his operations to history. The Israelis were the Crusaders marching up from the coastal plain, and Glubb's army was Saladin's defending the mountain redoubt of Jerusalem and the West Bank. ${ }^{44}$ Once battle was joined, the high ground gave defensive strength and any army that issued from Palestine's foothills onto the coastal plain - such as towards the Palestinian towns of Lydda and Ramle - would be exposed and crushed unless it could command the low ground. This operational perspective derived from history appeared in Glubb's defence reports to the British Amman Legation, where he used historical examples to prove that the party in the mountains of Palestine could hold off a stronger army on the plain. ${ }^{45}$ Glubb never intended to leave the safety of the hilly West Bank, saying from the beginning of the campaign that the Legion could not hold, for instance, Lydda and Ramle on the flat plain northwest of Latrun. For Glubb, the 'small numbers of the Arab Legion in comparison with the Israeli forces made it essential for us to fight in defiles at the foot of the mountains. Here, a single battalion could hold up the Israeli army, as indeed it had done at Latrun. But if a single battalion were to venture out into the open plain, it would be overwhelmed. ${ }^{46}$ Moreover, Glubb claimed that the Israelis knew this to be the case, wanting to draw out the Legion onto the coastal plain, as did Abdullah, and so he never appointed a military governor for the doomed towns of Lydda and Ramle. ${ }^{47}$ Glubb feared growing Israeli power relative to his own limited strength

41 P. J. Vatikiotis, Politics and the Military in Jordan: A Study of the Arab Legion (London, 1967), p. 84.

42 Morris, Road to Jerusalem, p. 121.

43 Glubb, Revised DNB.

44 Glubb, Soldier with the Arabs, p. 107.

45 Defence Document 1949, by Glubb, British Legation Amman, FO816/153, TNA.

46 Glubb, Soldier with the Arabs, p. 142.

47 Glubb, Soldier with the Arabs, p. 143. 
that was reliant on fickle British logistical backup, and of the need to occupy West Bank territory that was the size of Kent, Surrey, and Sussex combined, as he put it, with initially just four mobile battalions. ${ }^{48}$ Some Jordanian officers agreed with Glubb, challenging claims made by others that Glubb and his British officers retarded the Legion for political reasons and instead of deploying forward left isolated, for instance, Lydda and Ramle, subsequently captured by the Israelis who then expelled their Palestinian inhabitants. ${ }^{49}$ Others disagreed, al-Tall asserting that there was a British plot to safeguard Tel Aviv, an absurd claim. ${ }^{50}$ Abdullah and his Ministers summoned Glubb after the fall of the two towns, where 'it was made clear that his stories of ammunition shortages were disbelieved as part of British propaganda'. ${ }^{51}$

With Glubb's knowledge of history and sense of topography set alongside his army training, he fixed on Jerusalem as the operational pivot for the entire operation west of the Jordan, compounded now by the presence of 100,000 Israelis in the western city, in the old city's Jewish quarter, and in settlements in hills to the east. ${ }^{52}$ Jerusalem was 'the key to the military situation' for Glubb as from there the Israelis could advance downhill the short distance east to Jericho, seize the Allenby Bridge, and then 'the Arab Legion in Palestine would be cut off from its base, and would suffer a military disaster'. ${ }^{53}$ As Glubb wrote in a chapter draft, 'There seemed to be no alternative but to break into Jerusalem from the north, clear Sheikh Jarrah and establish contact with the Old City. Then a continuous line of defence could be built up across the city, and the Jewish offensive halted. If this were not done, it could only be a matter of two or three days before the Jews occupied all Jerusalem.' 54 Thus, regardless of Abdullah's entreaties - or the king's secret dealings with al-Tall - military imperatives pulled Glubb's troops into the war if Transjordan wanted control over any part of the West Bank. For Glubb, control of the West Bank required control of Jerusalem and control of the city meant control of the mountain ridges to the east, beyond the Valley of Kidron: Mount Scopus in the north through the Mount of Olives to Silwan, Mount Zion and Abu Tor, and beyond to Government House on Jabal Mukabbir, Abu Dis and Bethany (al-Eizariya). The Jewish foothold in the Hadassah hospital and Hebrew University on Mount Scopus, in the Jewish quarter, and especially their advance in Operation Kilshon into Sheikh Jarrah towards Mount Scopus threatened a strategic disaster for Glubb, putting the Israelis on the ridgeline beyond the old city looking down to the River Jordan. Through this fight, enemy forces also made percussive attacks on the Jaffa and Zion gates directly into the old city, observed by Anglican clergy. ${ }^{55}$ Jewish settlements beyond the old city such as

48 Glubb, Soldier with the Arabs, p. 98.

49 Abu Nowar, Jordanian-Israeli War, p. 119.

50 Pappé, Britain and the Arab-Israeli Conflict, p. 50.

51 Pirie-Gordon to Burrows (FO), 25 July 1948, FO816/127, TNA.

52 Bar-Joseph, Best of Enemies, pp. 68-9.

53 Glubb, Soldier with the Arabs, p. 107.

54 Chapter MS Drafts by Glubb, p. 10, 2006 Accession, Box 84, Bundle 1948 Jundis Account of Battle, GB165-0118 Glubb Papers, MEC.

55 Diary, Christchurch Jerusalem, 17 May 1948, 2006 Accession, Box 83, File November 1948, GB165-0118 Glubb Papers, MEC. 
Gush Etzion and Atarot threatened in the rear, and Arab troops destroyed them. Glubb laid out his precarious military position in a top-secret report dealing with the defence of Jerusalem. ${ }^{56}$ He reiterated this point when interviewed many years later. ${ }^{57}$ British Legion officers agreed with Glubb. The 'hysterical' appeals of the Jerusalemites for salvation in the face of the Israeli advance - 'All Arabs will be massacred! For God's sake, come and save us! Come! Come! Quickly!' - pulled Abdullah into a political call on the Legion to intervene with force, Glubb coming to the same conclusion but for military reasons. ${ }^{58}$ Glubb's lines of communication back to Amman were so tenuous and Transjordan Government budgets so tight that he raided Legion canteen funds to build a new road with press-ganged labour to help access the Ramallah and Nablus fronts. ${ }^{59}$ The war cut Glubb's supply line by land from Britain's Canal Zone in Egypt via Hebron, and he then depended on a sea route through Aqaba to Amman. Fitful logistics meant that deployment to Jerusalem would be limited to defensive action in the old city and its eastern suburbs as Glubb did not have the depot war supplies or logistical train to sustain offensive momentum. The Israelis were not keeping to their side of the bargain, with events on the ground leading policy, and not the other way around, and the question is whether success in Kilshon would have generated expanding Israeli advances beyond Jerusalem. This was Glubb's fear, judging by his papers and books. Kirkbride wrote about enemy aggression at the time, telling the Foreign Office on 19 May 1948 how 'the position became one of dealing with the Jewish offensive outside the Jewish State'. ${ }^{60}$ Once Glubb necessarily deployed to Jerusalem, he looked to establish a position at Latrun, again for reasons associated with topography and logistical interdiction.

Glubb moved the $4^{\text {th }}$ Mechanized Regiment to Latrun as it overlooked the Tel-Aviv to Jerusalem road and if he blocked Israeli traffic to Jerusalem his troops had a fighting chance in the city of keeping the Israelis off the eastern mountain ridgeline, as he recalled:

So to reduce the number of Israeli troops sent up into Jerusalem, this key position, we sent a battalion forward to the edge of the mountains and the plain where the road from Tel Aviv came across the plain and up through the mountains to Jerusalem. That's a place called Latrun. At that place we blocked the road from Tel Aviv to Jerusalem to prevent their building up a large army in Jerusalem which could have driven straight over into Jordan. ${ }^{61}$

Bar-Joseph intimates that the Jordanian commander of the $4^{\text {th }}$ Mechanized Regiment unilaterally moved his men to Latrun, presenting Glubb with a fait accompli: 'Once in Latrun, Glubb could no longer withdraw.' ${ }^{2}$ Glubb's papers do not support this. Glubb

56 Note on the Defence of Jerusalem, n.d. [c. late 1948-early 1949], 2006 Accession, Box 56, GB165-0118 Glubb Papers, MEC.

57 Glubb, 4410/06, pp. 40ff, I[mperial] W[ar] M[useum] S[ound] A[rchive].

58 Glubb, Soldier with the Arabs, p.101; Morris, Road to Jerusalem, p. 156.

59 Chapter, Draft, by Glubb, pp. 2-3, 2006 Accession, Box 84, Bundle November 1948 Finished with 10/10/56, GB165-0118 Glubb Papers, MEC.

60 Kirkbride to Secretary of State (FO), 19 May 1948, FO816/120, TNA.

61 Glubb, 4410/06, p. 45, IWMSA.

62 Bar-Joseph, Best of Enemies, p. 78. 
actively saw Latrun as a choke point and a place that if lost would unlock the entire West Bank to the enemy. Latrun was a strong position on a mountain spur with a thick-walled police fort, an artillery post on a 1,300-foot crest to the east, and a mass of trenches nearby. From 23 May, Legion troops at Latrun fought back four successive Israeli attacks that lasted in force to 18 July. Action in Latrun led to a related battle between Jerusalem and Latrun for the road from Abu Ghosh to Ramallah, and for Radar Hill northeast of $\mathrm{Abu}$ Ghosh. If the Israelis took Latrun or Radar Hill, they could have turned the Jerusalem front from the rear, via Ramallah, as they would do in the June 1967 Arab-Israeli war, 'isolating the occupying Legion forces within its walls', and taken all the West Bank. ${ }^{63}$ Glubb told Lash and his brigade commanders that his 'specific aim was to hold and defend every axis from west to east, to prevent Jewish forces from advancing through the environs of Jerusalem to Ramallah, thence to the River Jordan' ${ }^{64}$ There may well have been pre-war political arrangements to avoid fighting, but Glubb's papers set against the historical record are the account of a commander battling with insufficient resources and fluid operations on the ground.

\section{Glubb and Israeli designs on the West Bank}

Contra the collusion thesis, Glubb and his officers were unsure about Israeli designs on the West Bank, especially as successful enemy military action in Jerusalem and then Latrun would embolden them; hence the need to crimp Israeli operations that shifted the strategic balance. This determined the deployment of the Legion as detailed above. Glubb knew that Israeli successes could lead to further advances that would change the politics of the war, writing to Crocker before the war how it was 'possible that Arab resistance may be over before $15^{\text {th }}$ May, and the Jewish state be firmly established. What we do not know is whether the Jews will then have the self-control to limit themselves to the boundaries of the Jewish state, or whether they will get drunk with victory, and try and seize more.' ${ }^{65}$ On 1 May 1948, Glubb again wrote to Crocker detailing how the Jews were avoiding Arab areas but the 'snag is Jerusalem...the Jews will certainly try to capture the whole city from the Arabs. They will probably succeed' ${ }^{66}$ The military manoeuvres around Jerusalem before 15 May 1948 confirmed Glubb's fears and he later recalled how the 'Arab Legion never reached the borders of Israel as laid down by the United Nations. It everywhere encountered the Israeli forces in territory allotted the Arabs, which the Israelis had penetrated before the Arab Legion arrived on the scene.' 67 While Legion offensives were narrowly restricted to Jerusalem and were over by 28 May 1948 with the capture of the old city's Jewish quarter, Israeli attacks continued into August and September 1948, beyond the uneasy second truce of 18 July 1948. As one of the British

63 Dan Kurzman, Genesis 1948: The First Arab-Israeli War (London, 1972), p. 404.

64 Abu Nowar, Jordanian-Israeli War, p. 83.

65 Glubb to Crocker, 24 April 1948, 2006 Accession, Box 83, File Report and Letter 1940-48, GB165-0118 Glubb Papers, MEC.

66 Glubb to Crocker, 1 May 1948, ibid.

67 Foreword by Glubb, Peter Young, Bedouin Command: With the Arab Legion, 1953-56 (London, 1956), p. 6. 
officers wrote, 'the enemy sitting in his lair was obviously in rather a temper', not least as Glubb's men had beaten them. ${ }^{68}$ Legion war diaries are replete with Israeli ceasefire breaches, some of which were local actions by Irgun and LEHI forces. ${ }^{69}$ Legion intercepts of Israeli radio traffic confirmed that Revisionist Israeli forces planned to liberate Jerusalem 'completely' ${ }^{70}$ Local military actions were determining higher-level strategy and policy, according to Glubb. Writing to one of his British officers in 1982, Glubb remembered how the Israelis had hoped that everything would go off 'peacefully' but 'alas' the 'men with the guns were in control now, or would be as soon as the Mandate ended. There is no doubt that the Jewish (secret) army planned to conquer all Palestine to the Jordan as soon as the Mandate ended. British Army intelligence knew this as the G.O.C. [commander, Palestine] General [John] D'Arcy told me.'71 Probing, opportunistic Israeli actions for five months after the war began convinced Glubb that he faced an existential threat and not an agreeable partition of Palestine. As Jordanian Intelligence Officer Cadet Khalaf Shami put it on 26 July 1948, 'Notwithstanding truce terms, the enemy is attacking all posns [positions]. ${ }^{72}$ A month later, in August 1948, the $1^{\text {st }}$ Mechanized Regiment trained for street fighting in a ruined Jewish settlement in anticipation of more fighting in Jerusalem. ${ }^{73}$ Glubb may have misread Israeli intentions but he was reacting as he saw it to another attack, a military collapse, and the consequent evacuation of the West Bank. On 3 August 1948, Glubb wrote to MELF about sniping and tension in Jerusalem, concluding that the 'General opinion is that Jews attempting create chaos in Jerusalem so that they will have excuse to attack and try and take whole city. I told [UN envoy Count] Bernadotte today complete breakdown probable, unless UNO can show force. ${ }^{74}$ The next day he wrote again to MELF, noting ways in which Israeli successes had changed their plans: 'At end of first months fighting Arabs seemed to have advantage. In ten days fighting between first and second truce [8-18 July 1948] Jews proved obviously stronger. As result Jews now arrogant and intractable. ${ }^{75}$ As late as November 1948, Glubb expressed his fears of an all-out Israeli assault, writing to Goldie

68 Jerusalem Battle, 3 MR Arab Legion, by Lt-Col J. G. Newman, p. 5, 2006 Accession, Box 86, Bundle 4, GB165-0118 Glubb Papers, MEC.

69 War Diary, HQ Main Division AL, July 1948, 19 July 1948, p. 6, $3^{\text {rd }}$ Mechanised Regiment, 2006 Accession, Box 84, Bundle 1948 Jundis Account of Battle, GB165-0118 Glubb Papers, MEC; Arab Legion, War Diaries (Operational Log), 11 June 1948, 2006 Accession, Box 85, Bundle 1, 1948 Abdali Camp 1948 not wanted, GB165-0118 Glubb Papers, MEC.

70 Enemy news and wireless intercepts, 21 July 1948, 2006 Accession, Box 83, File August 1948, GB165-0118 Glubb Papers, MEC.

71 Glubb to Lunt, 26 May 1982, Lunt Papers 2009-08-51-89, NAM.

72 Intelligence Officer (Cadet Khalaf Shami) $1^{\text {st }}$ Motorised Regiment to OC $1^{\text {st }}$ Motorised Regiment to Divisional HQ, 26 July 1948, 2006 Accession, Box 83, File August 1948, GB165-0118 Glubb Papers, MEC.

73 War Diary, HQ Main Division AL, August 1948, p. 7, $1^{\text {st }}$ Mechanised Regiment, 2006 Accession, Box 84, Bundle 1948 Jundis Account of Battle, GB165-0118 Glubb Papers, MEC.

74 Arab Legion (Glubb) to Mideast (Pyman), 3 August 1948, 2006 Accession, Box 83, File August 1948, GB165-0118 Glubb Papers, MEC.

75 Arab Legion (Glubb) to Mideast (Pyman), 4 August 1948, ibid. 
that the enemy would attack Jerusalem, including a master plan of how Glubb as an Israeli would capture all of the West Bank, with attacks across the whole area:

What about the Jews dropping troops on to the Mt. of Olives by parachute during the attack?... The Jews obviously would not put in an attack on this scale on us, unless it were intended to be the decisive battle of the war. Do you think they could only produce two brigades? With only the Arab Legion and Iraqi Army in the field, and the Egyptians, Syrians and Lebanese right off the map, could not the Jews produce nearer 12 than 6 battalions? Our I [Intelligence] is so weak, that we don't know, but I think that we want to allow for it in considering our plans. ${ }^{76}$

The Legion on 30 May 1948 recorded an enemy parachutist dropped in Sheikh Jarrah, giving a sense of the heightened mood of danger; on 1 June, enemy planes bombed Amman. ${ }^{77}$ (The paratrooper story may have derived from Israeli attempts to airdrop supplies into the old city's Jewish quarter. ${ }^{78}$ ) Faced with such threats and the heavy combat after 18 May, Glubb considered a complete withdrawal of his troops, writing to Lash on 13 July 1948 that the Latrun salient was exposed, the Legion unable to man the front line, and,

In the event of a complete withdrawal from Palestine being necessary... we shall have to hang on to Jerusalem until the last moment... I think that Goldie's aim at this stage was to drop everything and tell everyone to get back over the Allenby Bridge as quickly as possible... The problem which baffles me is how to prevent all roads being blocked by refugee traffic. Could we not demobilize all civilian vehicles in Ramallah by removing some vital part? ${ }^{79}$

Glubb included stories of Israelis driving refugees into enemy lines to complicate their opponent's operations, as Germany had done in $1940 .{ }^{80}$ The broader fear that Israel would drive down to Jericho from the north and cross the River Jordan prompted demands for RAF intervention under the terms of the Anglo-Jordanian Treaty. The Legion was stretched thin, reliant on second-rate Iraqi troops to fill the front line in Samaria, as Glubb knew, writing to MELF in November 1948 on his military operations, which were complicated by political demands:

We are trying to cover far too much country. This is politics... We are spread from the Sea of Galilee to Beisan, from North of Latrun to Bethlehem and South of Hebron half way to Beersheba, and from the Dead Sea to Aqaba. With our manpower, this is ridiculous. The

76 Glubb to Goldie, 7 November 1948, 2006 Accession, Box 86, Bundle 5, GB165-0118 Glubb Papers, MEC.

77 Arab Legion, Operational Log/War Diary, 30 May and 1 June 1948, 2006 Accession, Box 90, Bundle Misc Dates, Part 3 of 3, GB165-0118 Glubb Papers, MEC.

78 Newspaper communiques, Sam P. Brewer (New York Times), 26 May 1948, 2006 Accession, Box 56, GB165-0118 Glubb Papers, MEC.

79 Glubb to Lash, 13 July 1948, 2006 Accession, Box 83, File November 1948, GB165-0118 Glubb Papers, MEC.

80 Glubb to Brig O’Connor (MELF), 20 November 1948, 2006 Accession, Box 86, Bundle 6, Part 2, GB165-0118 Glubb Papers, MEC. 
initiative lies entirely with the enemy... In order to get any ammunition, we must make it obvious that any breach of the truce is unilateral aggression by the Jews. We have hardly any ammunition... This... is $2 / 3$ political manoeuvring, which makes the military side complicated ${ }^{81}$

By 'politics', Glubb did not mean collusion to avoid fighting but the demand to spread his army too thinly. He feared Israeli attacks into Transjordan, by way of Beisan (Beit She'an) to Irbid and Mafraq, with only the recently agreed Anglo-Jordanian Treaty holding back any such assault: 'Attack the frontiers of Trans-Jordan between the Sea of Galilee and Beisan, and advance eastwards towards Irbid and Mafraq. The Jews could probably cross the Jordan here, but it is doubtful if they would venture eastward into the Trans-Jordan hills. They might also hesitate to invade Trans-Jordan for fear of bringing the Anglo-Transjordan treaty into effect.' ${ }^{82}$ Glubb's papers contain enemy intelligence intercepts reports, but these derive from open-source Hebrew-language radio stations, and he could only imagine the enemy's secret plans. For Glubb, his intelligence was 'so bad, that we cannot be certain that they [the Israelis] have also not trained a brigade or two of infantry to fight in the mountains. They have so many men that they can hold the front line with ordinary Hagana (in any rate in times of truce), and train their best troops in the back areas. None of our units ever get out of the front line.' 83 Glubb feared the destruction of the Legion and the loss of the West Bank, and he knew that he did not have supply lines to pour in the ammunition and weapons vital to sustain high-intensity defensive, let alone offensive, operations. The expenditure of ammunition by the Legion was phenomenal. Israeli troops in Nôtre Dame described the building as a 'sieve' after its pounding by Legion artillery at point blank range, the fighting like a 'continuous earthquake...sandbags, stonework and timber raining down all the time. In the midst of it, ten Legion tanks and armoured cars came storming up Suleiman's Way, a long string of infantry lorries behind them', the holding of the building a 'plain miracle'. ${ }^{84}$ It was worse at Latrun, where the battle extended over two months. It is a cliché, but one worth repeating, that amateurs talk tactics while professionals talk logistics; or, as the German commander Erwin Rommel put it, 'the battle is fought and decided by the quartermasters before the shooting begins'. ${ }^{85}$ The Legion's firepower was a force multiplier, for so 'long as the Legion had ammunition, its relatively small size was offset by a fire strike unparalleled in any other army in Palestine' ${ }^{86}$ Of course, if ammunition and weapons did not

81 Glubb [to MELF?], 9 November 1948, 2006 Accession, Box 86, Bundle 6, Part 1, GB1650118 Glubb Papers, MEC.

82 Appreciation of the Position of the Arab Legion in Palestine, 7 November 1948, 2006 Accession, Box 86, Bundle 6, Part 2, GB165-0118 Glubb Papers, MEC.

83 Glubb to Brig O'Connor (MELF), 20 November 1948, ibid.

84 Levin, Jerusalem Embattled, p. 196 (24 May 1948); Newspaper communiques, Sam P. Brewer (New York Times), 24 May 1948, 2006 Accession, Box 56, GB165-0118 Glubb Papers, MEC.

85 John A. Lynn, ed., Feeding Mars: Logistics in Western Warfare from the Middle Ages to the Present (Boulder, CO, 1993), p. ix.

86 Amitzur Ilan, The Origin of the Arab-Israeli Arms Race: Arms, Embargo, Military Power and Decision in the 1948 Palestine War (Houndmills, 1996), p. 47. 
increase in step with Legion expansion after May 1948, this superiority would dissipate or disappear. ${ }^{87}$

\section{British support for the Legion: recruits, logistics, and ammunition}

Supply of equipment and ammunition offers as good an explanation as any for the Legion's performance in 1948. The force fought with British weapons and ammunition, dressed in British army battledress, and ate British army rations. It functioned on British command and supplies, and London - under international pressure but also for its own reasons, as detailed by Bar-Joseph, Jevon, Pappé, and Shlaim - did not want an escalation of the war with Israel. The Legion took the war to the enemy as much as was practicable and necessary, but this would be impossible if Britain starved the force of British officers and MELF-sourced supplies. ${ }^{88}$ Glubb's papers when triangulated with UK Government files address this issue in interesting ways, and inform a new military history of the Arab Legion. The British enforced on 29 May an arms embargo on Transjordan as a protagonist in the war and they nominally withdrew their officers not on private contracts from the Legion on 30-31 May. The argument here is that Britain neither withdrew its officers nor fully enforced the arms embargo, so allowing the Legion to function and fight, up to a point, with MELF arranging supplies of matériel and accepting delayed payment for supplies. ${ }^{89}$

Before examining logistics, there is the question of Britain ordering its officers to leave the war zone. Such a move would have hollowed out the Legion's command echelons and considering the importance of British officers would have rendered the force inoperable. Glubb made this point in late July 1948, writing that the withdrawal of officers had been a 'terrible blow to us'.$^{90}$ Glubb's assessment does not match the evidence presented here. First, those ordered to leave were only to remove themselves from the West Bank, not Transjordan. It was therefore straightforward to move them back after a suitable hiatus, if they ever left at all. Dan Kurzman argued that in truth the British never departed. He stated: 'the day that [Ernest] Bevin [British Foreign Secretary] was to tell Parliament that not a single regular British soldier was still in Palestine [26 May 1948], Glubb had sent all of his officers across Allenby Bridge into Transjordan. On receiving word that Bevin had completed his speech, he ordered the men back to their posts. ${ }^{9} 1$ British officers made the same point, Goldie later told Shlaim. 'B[ritish] officers were withdrawn on 30 May? We were withdrawn for just 2 days to enable Bevin to make a speech. Bevin said: there are no B[ritish] officers serving with the Arab Legion. It was

87 Ilan, The Origin of the Arab-Israeli Arms Race, p. 48.

88 See also Yitzhak Ronen, 'British Military Supplies to Jordan during the 1948 War: How the Anglo-Jordanian Treaty was Put to the Test', Middle East Critique 24/4 (2015), pp. 345-54.

89 See also Mary Wilson, King Abdullah, Britain and the Making of Jordan (Cambridge, 1987), pp. 176-7.

90 Glubb to Maj-Gen. Pyman (MELF), 27 July 1948, 2006 Accession, Box 86, Bundle 4, GB165-0118 Glubb Papers, MEC.

91 Kurzman, Genesis 1948, p. 431. 
correct when he said it. But we returned...two days later. ${ }^{92}$ Indeed, on 16 July 1948, Israeli fire wounded a Captain Gray in Jerusalem..$^{93}$

The British Government discussed in detail the status of its officers serving in Transjordan, triaging them into those officially on attachment from the army, those officially seconded from the Palestine colonial service, and those on private contracts, and it only expected men in the first two categories to leave. ${ }^{94}$ While officers on contract were 'not affected' by any order to leave, they were liable to prosecution under the anti-mercenary 1870 Foreign Enlistment Act forbidding British subjects from serving in a foreign army at war with another country at peace with the UK. ${ }^{95}$ However, the Foreign Office read generously Article 4 of the 1870 legislation, arguing that British subjects already employed by a warring party before hostilities commenced were exempt from prosecution..$^{96}$ They had joined the foreign state at war before war began. Some men who went as attached officers switched to private contracts when their army service expired, and that they originally joined on attachment meant that they were not obviously mercenaries. Kirkbride included these officers when he informed the Foreign Office that all British officers except two 'did in fact join the Arab Legion with His Majesty's licence' ${ }^{97}$ The Foreign Office made clear on 28 May 1948 that if officers' service started before 15 May they were safe from legal proceeding: 'On further consideration, we have come to the conclusion that the Foreign Enlistment Act does not apply at all to persons who accepted service at a time when no hostilities were in progress... You may therefore assure Brigadier Glubb that neither he nor any of those in a similar position can or will be regarded as having committed an offence under the Act. ${ }^{98}$ The British volunteers who went to fight in the Spanish Civil War had proved the practical problems of prosecuting British subjects under the Act (none was ever prosecuted), compounded in 1948 by the fact that Britain did not recognize Israel, only de facto doing so in January 1949. ${ }^{99}$ The Foreign Office absolved all British officers in the Legion, on contract or otherwise, and none was prosecuted, not even those who joined on contract after 15 May. The Foreign Office made little comment on 'other ranks' in the Legion. The subterfuge was obvious, the issue being the appearance of compliance, and ensuring that men served under private contract where appropriate, so severing official connections to the UK Government, in return for which they would escape prosecution. When the Air Ministry contacted the Foreign Office regarding the release of an RAF officer for service with the Legion, the Foreign Office noted frankly how if 'only the stupid man had made no mention of the

92 Avi Shlaim, interview with Goldie, 15 September 1985.

93 War Diary, OC $3^{\text {rd }}$ Brigade, 2006 Accession, Box 86, Bundle 4, GB165-0118 Glubb Papers, MEC.

94 Kirkbride to Gault (FO), 25 March 1947, T220/126. TNA.

95 Lunt, Arab Legion, p. 117.

96 Foreign Office to Amman, 7 May 1948 (sent 8 May 1948), FO371/68852, TNA.

97 Kirkbride to Burrows (FO), 13 May 1948, FO371/68854, TNA; Telegram, Foreign Office to Kirkbride, 29 May 1948, FO371/68854, TNA.

98 FO to Amman, 28 May 1948 (sent 29 May 1948), CO537/3579, TNA.

99 Nir Arielli et al., 'The Foreign Enlistment Act, International Law, and British Politics, 1819-2014', The International History Review 38/4 (2016), pp. 636-56. 
Arab Legion but had merely said he wanted to accept the offer of a job in Amman no one would have had any suspicion and the release would have gone through with no trouble at all'. ${ }^{100}$ When Bevin faced Parliament on 26 May, he disingenuously said that only one British officer had been involved in 'certain fighting in Jerusalem' but he would 'check this up', and that the 'remainder' of officers 'have not been involved in any fighting'. 101 This was a lie, as the wounded British officers cited above prove. Bevin added that no officers fought in the old city and only two in the 'new part', disregarding the British officers who went into the old city during the battle to liaise with the Jordanian-led garrison companies and Arab irregulars conducting the fighting inside and on the old city's walls. ${ }^{102}$ They were linked battles, the fight for the new city providing the diversion for the capture of the Jewish part of the old one. ${ }^{103}$ Bevin deflected questions from MPs Sydney Silverman and Leslie Solley on whether British soldiers were stoking the fire of war, replying firmly, 'If I am out of Order you, Mr Speaker, will tell me to sit down... The trouble about the fighting in Jerusalem arose owing to the truce being broken, and it was broken by a section of the Jewish Forces.' 104

Britain was equally pragmatic with the supply of arms and ammunition. One of Glubb's officers later wrote that for sixteen months when fighting Israel, 'the Arab Legion had to fight a war with an ammunition supply intended by British calculations to be sufficient for one battle only'. ${ }^{105}$ The military measure for ammunition stocks was for front-line use or 'contact days', also expressed as $1^{\text {st }}$ and $2^{\text {nd }}$ line ammunition, carried respectively by field units and depots. The Legion was supposed to have at least thirty contact days of ammunition. Egypt's seizure of the Ramses on 22 May, the second of two boatloads of British-supplied ammunition leaving Egypt and destined for Aqaba - the ammunition redirected to the Egyptian army - meant the loss of 350 tons of ammunition. (One MELF file gives a date of 17 May for the seizure. ${ }^{106}$ ) There were 500 tons of ammunition in total on both ships and only 150 tons got through on the first ship, mostly small-arms ammunition as the second boat carried the heavier artillery shells, such as for the 25-pounders. ${ }^{107}$ The delivery of 500 tons of ammunition was to bring the Legion's contact day stock to thirty days' supply, which the first ship achieved for .303 rounds, the bullets for British-supplied rifles and machine guns. Indeed, MELF noted on 1 July 1948 how low the Legion was 'in all natures' of ammunition except .303 rounds. ${ }^{108}$ Before the British could make good the loss of the Ramses, the arms embargo came into force, leaving the Legion short of heavy ammunition, and neighbouring Arab states failed to make

100 Note by Walker (FO), 14 May 1948, FO371/68853, TNA.

101 Hansard, Parliamentary Debates, Commons, Vol. 451, 26 May 1948, p. 187.

102 Ibid.; Bevin in Extract from Official Report, 26 May 1948, CO537/3579, TNA.

103 Abu Nowar, Jordanian-Israeli War, p. 110; Jerusalem Battle, 3 MR Arab Legion, by Newman, p. 4, 2006 Accession, Box 86, Bundle 4, GB165-0118 Glubb Papers, MEC.

104 Bevin in Extract from Official Report, 26 May 1948, CO537/3579, TNA.

105 Lunt, Glubb Pasha, p. 140.

106 Ilan, Origin of the Arab-Israeli Arms Race, p. 37; Kirkbride to FO, 23 May 1948, CO537/3902, TNA; 17 May, see C-in-C MELF to WO, 27 May 1948, WO32/12263, TNA.

107 Ilan, Origin of the Arab-Israeli Arms Race, p. 122.

108 C-in-C MELF to WO, 1 July 1949, WO32/15561, TNA. 
good the shortfall, Syria and Egypt proving to be 'broken reeds' when it came to helping Transjordan. ${ }^{109}$ The Arab League and Egypt were hostile to Abdullah and the 'highhanded action' of seizing the Ramses meant that 'the last opportunity for the Legion to replenish its stocks before the general embargo on the issue of supplies and money was imposed by Great Britain' passed. ${ }^{110}$ The War Office calculation was that the Egyptians seized ' 16 days contact' on the Ramses. ${ }^{111}$ Glubb asserted that he fought a forty-day battle with a ten-day contact allotment but, as he admitted, more exactly he had forty days of ammunition for lighter weapons but only ten contact days for heavier guns. ${ }^{112}$ Certainly, the Legion did not have limitless ammunition supplies but it had sufficient to fight two linked battles for Jerusalem over ten days, four successive battles for Latrun over two months, skirmish near Radar Hill, deploy small units to Lydda and Ramle, and manoeuvre and engage all across the West Bank and Negev to March 1949. Street fighting in Jerusalem ate up ammunition - 'an intensity equal to that of European warfare' and Glubb's soldiers poured fire onto attacking Israeli troops at Latrun. ${ }^{113}$ The War Office assessed in January 1949 that the Legion consumed in a few months a year's worth of supplies and ammunition. ${ }^{114}$ If the Legion had only a boosted ten days' contact ammunition stock, it would have had to stop fighting and withdraw by the end of May 1948. The analysis here accepts that ammunition and weapons re-supply were fitful and inadequate - and does not want to repeat this point, well made in accounts of the war - and that this fed into Glubb's cautious operational deployment, but Britain did not turn off the logistical tap on 15 May 1948. Instead, Britain, as with its removal of British officers, reclassified and extemporized so that it could keep its ally in the war.

Britain did not dissemble and secretly supply Transjordan with military equipment, or at least the London ministries did not. Government files prove that in late May and early June, the Foreign and War offices enforced the arms embargo, blocking attempts by MELF on 1 June 1948 to reclassify military stores such as mines as 'defensive' to circumvent the arms embargo. ${ }^{115}$ MELF persevered, sending numerous cables pushing London to permit it to send equipment to the Legion, and on 15 June it got the green light to send heavy engineering equipment and vehicles, 'stores not covered by embargo'.116 Similarly, London in July 1948 authorized 'eight months stock pile based on ME scale 14 for 8600 issued to Arab Legion' that seems to refer to food rations. ${ }^{117}$ MELF challenged the arms embargo, writing to London on 25 June 1948 that it put alliances such as with Transjordan in 'danger': 'By treaty we have stipulated that the organisation of these

109 Pirie-Gordon to Burrows (FO), 25 July 1948, FO371/68822, TNA.

110 Alec Kirkbride, From the Wings: Amman Memoirs 1947-51 (London, 1976), pp. 24-5.

111 WO to C-in-C MELF, 16 June 1948, WO32/15562, TNA.

112 Trans-Jordan Situation by Glubb, 12 August 1948, FO371/68822, TNA.

113 Glubb to Kirkbride, 4 August 1948, 2006 Accession, Box 83, File August 1948, GB1650118 Glubb Papers, MEC.

114 WO Note, 31 January 1949, WO32/15561, TNA.

115 C-in-C MELF to WO, 1 June 1948, WO32/15562, TNA.

116 WO to C-in-C MELF, 15 June 1948, WO32/15562, TNA; C-in-C MELF to WO, 15 June 1948, WO32/15562, TNA.

117 C-in-C MELF to WO, 12 July 1948, WO32/12263, TNA. 
armed forces shall be generally on British lines and have agreed that British weapons and equipment shall be supplied.' 118 The Foreign Office later 'cloaked' supplies under the 'guise of internal security stores'. ${ }^{119}$ MELF was the local nexus for equipment supply, creatively reclassifying equipment to circumvent the arms embargo. MELF had configured the Legion as integral to itself: an attached allied force designed to fight alongside the British and with access to MELF's huge Canal Zone supply dumps.

MELF was the major supplier to the Legion and its support depended on how it classified the force. MELF asked the War Office before the war if the Legion was now a 'foreign army', as this would influence its supply of equipment. ${ }^{120}$ The War Office replied ambiguously, saying that after 15 May 1948 the Legion would be 'an independent foreign army', but under treaty obligations Britain would supply arms and for this the Legion was a 'contingent force' in financial estimates, later called 'estimates customer'. ${ }^{121}$ This meant that MELF 'should continue to give Arab Legion every assistance by the provision of maintenance' from its stocks. ${ }^{122}$ Kirkbride and Glubb saw the significance of this. Glubb told Kirkbride in June 1948 that this 'means (I understand) that the War Office admits at least a certain amount of responsibility for making arrangements work. If unforeseen circumstances arise, the British Army will take appropriate action to keep the force efficient.' ${ }^{123}$ This included maintaining secret stocks of ammunition on Transjordanian RAF bases for use if Israel invaded, or breaking the embargo and flying in stocks from Egypt, allowing Glubb to deplete his ammunition to a bare minimum, as he had reserves in extremis. ${ }^{124}$ Glubb added an example for Kirkbride of how armies in need of stock, such as an axle, had to order and pay for a fixed number in advance. If they ordered too many, none could be sent back; if they ordered too few, they would need to put in a new order and pay again. Glubb's axle analogy made the point that the Legion had most favoured status as a contingent force and could indent for what it wanted, when it wanted it, exactly to requirements, off the shelf. ${ }^{125}$ Transjordan was a special case. British army depots were huge stores for the Legion, if it could pay, and with contingent status came the added benefit that the British army gave credit to buy now and pay later, or, as happened, leave the British Government to pick up the bill. ${ }^{126}$

The Legion had at least twenty-four 25-pounders and not the eight guns detailed above. ${ }^{127}$ This is instructive. MELF enhanced Legion war supplies before and during

\footnotetext{
118 MELF to MoD London, 25 June 1948, WO32/12263, TNA.

119 WO to C-in-C MELF, 7 July 1949, WO32/15561, TNA.

120 Status of Arab Legion, C-in-C MELF to WO, 5 May 1948, WO32/15562, TNA.

121 WO to C-in-C MELF, 13 May 1948, WO32/15562, TNA.

122 WO to C-in-C MELF, 13 May 1948, WO32/15562, TNA.

123 Glubb to Kirkbride, 17 June 1948, WO32/15562, TNA.

124 Kirkbride, From the Wings, p. 36; Munitions for Arab Countries by Foster, 1 November 1948, AIR8/1798, TNA; Note by Glubb Pasha, 19 August 1948, FO371/68822, TNA; Arab Legion Ammunition, 2006 Accession, Box 86, Bundle 6, Part 2, GB165-0118 Glubb Papers, MEC; WO to C-in-C MELF, 24 June 1948, WO 32/15562, TNA.

125 Glubb to Kirkbride, 17 June 1948, WO32/15562, TNA.

126 FO to Amman, 24 January 1949, T220/129, TNA.

127 Morris, Road to Jerusalem, p. 121.
} 
the early stages of the war. MELF was restructuring the Legion before the war, and in January 1948, faced with the difficulties of the Palestine withdrawal, it proposed 'to transfer eight months maint[enance] from Palestine to Transjordan in all commodities based on present org[anization] and str[ength] of Legion'. ${ }^{128}$ The Foreign Office replied on 18 February 1948 saying that it had 'no objection to the proposal' that eight months' supply of 'maintenance stores for the Arab Legion should be transferred forthwith to Transjordan from Palestine'. ${ }^{129}$ Two days later, the War Office authorized MELF to transfer eight months' 'maintenance' supplies to the Legion. ${ }^{130}$ The War and Foreign offices along with the Treasury had earlier discussed the issue of whether the supply of equipment to the Legion 'would conflict with H.M.G.'s public declaration on the subject of supply of arms and equipment to the Arab states'. ${ }^{131}$ They concluded that it would not, citing the treaty arrangement with Transjordan and that equipment was in the 'pipeline', and 'His Majesty's Government have no reason to suppose that the material supplied by them under such contracts will be used in Palestine.' 132 The original two batteries of eight 25-pounders seem to have arrived in Transjordan in February 1948. In March 1948, the Palestine High Commissioner informed the Colonial Office that the War Office had ordered the transfer of 'certain major items of equipment including 25 pounder guns and 6 pounder anti-tank guns' from the army in Palestine to the Legion. ${ }^{133}$ He added that 'it is possible that further items will have to be supplied from Palestine. I assume that this arrangement, which may cause some comment if it comes to Jewish ears, has been cleared with you by the War Office.' 134 The Colonial Office replied that supply of the Legion from Palestine 'could be effected with less publicity than supply from other Middle East sources'. ${ }^{135}$ In April 1948, MELF spoke of 'issuing' first-and second-line ammunition for the Legion, as authorized on 19 February $1948 .{ }^{136}$ A month later, MELF shipped civilian stores for the Legion from Egypt, as well as petrol and Oerlikon anti-aircraft ammunition, on Egyptian-flagged ships to Aqaba. ${ }^{137}$ Understandably, the Jews complained about such actions, reporting to the UN in March 1948 that 'British army supplies were transferred from Egypt to Rafah in Palestine for the use of the Arab Legion. Included in these stores were charging sets, artillery stores, anti-tank rifles and mortars.' ${ }^{138}$ MELF equipment in Egypt and Palestine flowed into Transjordan before the arms embargo. The Legion was based in Palestine in early 1948 and the Foreign Office was 'very glad' to see the force 'so far as possible...take over the

128 C-in-C MELF to WO, 27 January 1948, FO371/68828, TNA.

129 Walker (FO) to Leask (WO), 18 February 1948, FO371/68828, TNA.

130 WO to GHQ MELF, 20 February 1948, FO 371/68828, TNA.

131 Equipment for Arab Legion, Notes of meeting, 6 February 1948 attended by representatives of the WO, FO and Treasury, FO371/68828, TNA.

132 Ibid.; Burrows (FO) to Charteris (WO) 16 February 1948, FO371/68828, TNA.

133 Cunningham Palestine to Secretary of State (CO), 4 March 1948, FO371/68828, TNA.

134 Ibid.

135 Secretary of State (CO) to Cunningham Palestine, 10 March 1948, ibid.

136 C-in-C MELF to War Office, 20 April 1948, WO32/12263, TNA.

137 C-in-C MELF to WO, 11 May 1948, ibid.; C-in-C MELF to WO, 13 May 1948, ibid.

138 Jewish Agency to UN Palestine Committee, 19 March 1948, FO371/68829, TNA. 
equipment in Palestine so that they will carry it with them when they withdraw. And we hope that as much as possible will be handed over to them in this way. ' ${ }^{39}$ By such means, the Legion boosted its equipment levels before the war. Nor did this suddenly change when war started, with the MELF pipeline remaining open to early June in some accounts. ${ }^{140}$

There were also semi-legal and illegal supply routes for arms and ammunition. A Legion quartermaster noted that ammunition shortages were no great handicap, adding that the British left them all their supplies when they left Palestine, that Britain faithfully delivered orders placed by Amman, and that his men 'borrowed' British ammunition during the fighting. ${ }^{141}$ Britain estimated that the withdrawal from Palestine meant that 'even under the most favourable conditions' it would 'lose nearly 150,000 tons of useful stores'. ${ }^{142}$ MELF even sold to local agents in Palestine 'without discrimination' $£ 2,762,000$ of 'non-warlike stores and equipment'. ${ }^{143}$ Haemorrhaging of stores lifted Legion equipment levels further. The British held security conferences to tackle the sale of arms by British officers to Arabs. ${ }^{144}$ Thieves stole army trucks in Egypt that 'might also find their way into Palestine'. ${ }^{145}$ Arabs stole arms and parachutes, Servicemen sold arms, and military police guarded stocks of British ammunition, with Summary Courts established to hand out 'worthwhile' sentences to thieves. ${ }^{146}$ In November 1947, the British reported 80,000 rounds of rifle ammunition as lost. ${ }^{147}$ Such things were so blatant that local shops openly sold British army battledress. ${ }^{148}$ Iraqi troops fighting with the Legion also brought with them arms and ammunition, of British design, leaving behind 6,300 25-pounder shells when they returned home. ${ }^{149}$ The Legion independently purchased supplies from countries such as Sweden and Ireland, London later noting how it 'was disconcerting to find that the Arab Legion had made such purchases without any consultations with the Foreign Office'. ${ }^{150}$ Amman also bought weapons from

139 Walker (FO) to Leask (WO), 10 March 1948, FO371/68828, TNA.

140 Ilan, Origin of the Arab-Israeli Arms Race, p. 25.

141 Godfrey Ilias, Glubb's Legion (London: Evans, 1956), pp. 191-93.

142 Secretary of State (CO) to Cunningham Palestine, 28 November 1947, Box 2, File 3, GB 165-0072 Cunningham Papers, MEC.

143 Hansard, Parliamentary Debates, Commons, Vol. 451, 1 June 1948 (written answers), p. 69.

144 Minutes, Palestine High Commissioner (Security) Conference, 16 October 1946, Box 4, File 1 Sheet 18, GB 165-0072 Cunningham Papers, MEC.

145 Minutes, Palestine High Commissioner (Security) Conference, 24 January 1947, Box 4, File 1 Sheet 29, GB 165-0072 Cunningham Papers, MEC.

146 Minutes, Palestine High Commissioner (Security) Conference, 6 June 1947, Box 4, File 1 Sheet 59, GB 165-0072 Cunningham Papers, MEC.

147 Minutes, Palestine High Commissioner (Security) Conference, 29 November 1947, Box 4, File 1 Sheet 98, GB 165-0072 Cunningham Papers, MEC.

148 Minutes, Palestine High Commissioner (Security) Conference, 19 December 1947, Box 4, File 1 Sheet 104, GB 165-0072 Cunningham Papers, MEC.

149 Baghdad to FO, 16 July 1949, WO32/15561, TNA.

150 Treasury, War Office and Foreign Office Meeting, 28 June 1949 (Minutes dated 14 July 1949), WO32/15561, TNA. 
Belgium. ${ }^{151}$ Creative use of the British-supplied budget gave a surplus for such purchases, as this article will now detail.

Purchasing equipment required a budget and Glubb used the indent facility for stock to overspend, far beyond agreed budgets, leaving a financial hole that left the Foreign Office aghast. The British Legation in Amman helped with the budget, asking, for instance, in March 1948, 'that in view of the tricky position which will develop in May it would be of very great advantage if the Arab Legion could have the whole year's grant already in hand before the correctness of their future international behaviour can be called in question'. ${ }^{152}$ But Glubb simply overspent. Kirkbride noted on 5 August 1948 that Glubb had seen him,

....and reported an almost incredible state of affairs financially. Acting on a verbal promise that Arab Legion funds would be made available which [Abd al-Rahman] Azzam [Secretary-General, Arab League] made to Glubb some time ago, the latter admits having over spent his current yearly estimate to the tune of about $£$ Palestine 400,000 (I fear it may be more). Over expenditure was incurred by payment to enlisted personnel of the Arab Legion over the approved establishment of the Force and by equipment and payment to volunteers for operating in Palestine under the general direction of the Arab Legion. The most astounding feature of the matter is that Glubb did this without any reference to the Transjordan Government either as regards promise of cash or actual expenditure. This Legation was kept equally ignorant until yesterday. ${ }^{153}$

The Amman Legation confessed to Bevin that 'it is now apparent that serious and unauthorised over expenditure and financial commitments have been incurred by the Arab Legion' ${ }^{154}$ Glubb acted unilaterally, keeping the Legion finance officer 'in the dark as to the true position and that all the additional equipment, ammunition and supplies had been ordered as an emergency by General Glubb himself without any reference to the department in his own office responsible for arranging and paying for such purchases'. ${ }^{155}$ The 'substantial debt' accrued by the Legion to the War Office was the force 'using every resource to obtain additional supplies', noted the Foreign Office in 1949. ${ }^{156}$ Glubb's creative accounting provided the budget for the Legion to access war supplies for its battle with Israel, beyond the basic supply levels cited in most sources.

\section{Conclusion}

This study complements and challenges existing political and military histories of the Arab Legion and the 1948 war. It offers an alternate reading of the Legion. It puts the

\footnotetext{
151 Burrows (FO) to Charteris (WO), 16 February 1948, WO32/15562, TNA; Brussels to FO, 12 April 1948, FO371/69201, TNA.

152 Pirie-Gordon to Burrows (FO), 10 March 1948, FO371/68829, TNA.

153 Kirkbride to FO, 5 August 1948, FO371/68830, TNA.

154 Amman Legation (Kirkbride?) to Bevin, 9 August 1948, FO371/68830, TNA.

155 Ibid.

156 FO to Amman, 24 January 1949, FO371/75299, TNA.
} 
war centre stage, arguing that operational needs as Glubb saw them are as good an explanation as any for the actions of the Legion - the conduct of military operations as opposed to the conduct of political collusion. To borrow from Occam's Razor, there is no need to look for a complicated political explanation when a simple military one will do. That said, matching Glubb's thinking to his operational needs has not been easy; nor has it been straightforward relating Glubb's cautious approach to the fact that he had better supplies of matériel than is usually allowed for in accounts of the war. The explanation offered here is that without these enhanced supplies the Legion would have collapsed by the end of May 1948. British-supplied equipment and attached British soldiers - often surreptitiously given - gave the Legion the power to continue to the war's end, making it militarily powerful and effective - 'the master of the battlefield', in Glubb's words. ${ }^{157}$ Glubb intended to control certain portions of Palestine for military and not political reasons, the needs of the former outweighing those of the latter, at least while he fought Israel.

\section{Acknowledgements}

The author acknowledges Graham Jevon and Avi Shlaim for their help with source material used for writing this article; Brunel University for research leave and funding to visit archives; Debbie Usher at the Middle East Centre, St Antony's College for her assistance with the Glubb papers; the anonymous referees for their helpful comments; and the Parliamentary Archives at the Houses of Parliament for Hansard material not available on-line.

\section{Funding}

This research received no specific grant from any funding agency in the public, commercial, or not-for-profit sectors.

\section{Author Biography}

Matthew Hughes teaches history at Brunel University. Previously, he held the Maj-Gen Matthew C Horner Chair in military theory at the US Marine Corps University. His book on Britain's pacification of the Arab revolt in Palestine in the 1930s will be published later this year by Cambridge University Press.

157 Glubb, Soldier with the Arabs, p. 132. 